\title{
Profil penderita sepsis di ICU RSUP Prof. Dr. R. D. Kandou Manadoperiode Desember 2014 - November 2015
}

\author{
${ }^{1}$ Rheza N. Tambajong \\ ${ }^{2}$ Diana C. Lalenoh \\ ${ }^{2}$ Lucky Kumaat
}

\author{
${ }^{1}$ Kandidat Skripsi Fakultas Kedokteran Universitas Sam Ratulangi Manado \\ ${ }^{2}$ Bagian Anestesi dan Reanimasi Fakultas Kedokteran \\ Universitas Sam Ratulangi Manado \\ Email: tambajong.rheza@yahoo.com
}

\begin{abstract}
Sepsis (blood poisoning) is an acute and serious clinical condition due to the presence of pathogenic microorganisms or their toxins in the bloodstream. The incidence of sepsis continues to rise over the past three decades. Although the knowledge of pathophysiology and therapy has developed supported by specific antibiotic therapy, sepsis is still the main cause of non-cardiac death in Intensive Care Unit (ICU). This study was aimed to determine the profile of patients with sepsis and its classification in the ICU. This was a descriptive retrospective study. Samples were determined by using non-probability sampling method, the purposive sampling method. Samples were septic patients at ICU Prof. Dr. R. D. Kandou Hospital Manado obtained from data of the medical records from December 2014 to November 2015. The results showed that there were 35 septic patients consisted of 16 males (46\%) and 19 females (54\%); most were geriatric patients. There were 29 patients $(82.8 \% 4$ patients) diagnosed as sepsis; 4 patients (11.4\%) as severe sepsis; and 2 patients (5.7\%) as septic shock. Of the total 35 patients, there were 12 survivors (34.3\%) and 23 deaths (65.7\%)
\end{abstract}

Keywords: septic patients

\begin{abstract}
Abstrak: Sepsis adalah kondisi klinis akut dan serius yang muncul akibat adanya mikroorganisme patogen atau toksinnya dalam aliran darah. Kejadian sepsis terus meningkat selama tiga dekade terakhir, Meskipun pemahaman patofisiologi dan terapi meningkat serta didukung oleh terapi antibiotik yang spesifik, sepsis dilaporkan tetap menjadi penyebab dari kematian non-cardiac di Intensive Care Unit (ICU). Penelitian ini bertujuan untuk mendapatkan profil penderita sepsis dan klasifikasinya di ICU. Jenis penelitian ialah deskriptif retrospektif. Sampel penelitian ialah pasien ICU RSUP Prof. Dr. R. D. Kandou Manado dengan diagnosis sepsis dan klasifikasinya diperoleh dari data di Bagian Rekam Medik periode Desember 2014 - November 2015. Besar sampel ditentukan dengan metode purposive sampling. Hasil penelitian mendapatkan total 35 sampel dengan sepsis terdiri dari 16 orang laki-laki (46\%) dan 19 orang perempuan (54\%); sebagian besar ialah pasien geriatri. Pasien yang didiagnosis masuk sepsis yang terbanyak yaitu 29 orang $(82,8 \%)$ dibandingkan dengan diagnosis lain yaitu severe sepsis sebanyak 4 orang $(11,4 \%)$ dan syok sepsis sebanyak 2 orang $(5,7 \%)$. Dari ke 35 pasien dengan sepsis, 12 orang berhasil selamat (34.3\%) sedangkan 23 orang meninggal (65.7\%).
\end{abstract}

Kata kunci: pasien sepsis

Pada tahun 1991, American College of Chest Physicians and Society of Critical Care Medicine mengadakan konferensi untuk mendapatkan pengertian yang seragam tentang sepsis dan gejalanya, berdasarkan gejala klinis umum seperti 
perubahan suhu tubuh, takikardia, takipnea, dan abnormalitas sel darah putih. ${ }^{1}$ Septikaemia atau sepsis (keracunan pada darah) adalah kondisi klinis akut dan serius yang muncul sebagai akibat adanya mikroorganisme patogen atau toksinnya dalam aliran darah. ${ }^{2}$ Sepsis dapat disebabkan oeh infeksi bakteri Gram negatif 70\% (Pseudomonas aeruginosa, Klebsiella, Enterobacter, E. Colli, Proteus, Neisseria), infeksi bakteri Gram positif 20-40\% (Staphyllococcus aureus, Streptococcus, Pneumococcus), infeksi jamur dan virus 2$3 \%$ (dengue haemorrhagic fever, herpes viruses), protozoa (malaria falciparum). ${ }^{3}$

Kejadian sepsis terus meningkat selama tiga dekade terakhir, setidaknya sebagian karena penuaan populasi Barat. Hampir $15 \%$ dari pasien yang di rawat di ruang rawat intensif dengan severe sepsis, dimana dua pertiga dari pasien-pasien tersebut mengalami syok septik. Meskipun pemahaman patofisiologi dan terapi meningkat, didukung oleh terapi antibiotik yang spesifik, sepsis dilaporkan tetap menjadi penyebab dari kematian noncardiac di Intensive Care Units (ICUs). Angka kematian tetap tinggi dan sepsis menjadi penyebab kematian tertinggi dibandingkan penyakit-penyakit umum lainnya di negara-negara barat seperti myocard infarct, stroke dan trauma. ${ }^{1} \mathrm{Di}$ Indonesia tingkat penyebaran dari penyakit sepsis di Rumah Sakit Dr. Sutomo ialah penderita yang jatuh dalam keadaan sepsis berat sebesar $27,08 \%$, syok septik sebesar $14,58 \%$, sedangkan $58,33 \%$ sisanya hanya jatuh dalam keadaan sepsis. ${ }^{4}$

Penelitian ini bertujuan untuk mendapatkan profil penderita sepsis di ICU RSUP Prof. Dr. R. D. Kandou Manado.

\section{METODE PENELITIAN}

Jenis penelitian ini ialah deskriptif retrospektif. Populasi ialah semua penderita sepsis di RSUP Prof. Dr. R.D. Kandou Manado. Sampel ialah semua penderita sepsis serta klasifikasinya yang dirawat di ruang ICU RSUP Prof. Dr. R.D. Kandou Manado yang memenuhi kriteria inklusi, diperoleh dari data Rekam Medik pasien ICU periode Desember 2014-November 2015.

Besar sampel ditentukan dengan metode non probability sampling yaitu purposive sampling. Variabel penelitian ialah jenis kelamin, usia, infeksi sepsis menurut penyakit dasar, lama rawat pasien di ruang rawat intensif, dan angka kematian.

\section{HASIL PENELITIAN}

Berdasarkan data yang diperoleh, jumlah pasien dengan diagnosais sepsis, severe sepsis dan syok sepsis periode November 2014-November 2015 sebanyak 35 orang terdiri dari 19 perempuan dan 16 laki-laki.

Pasien yang dirawat di ICU dengan diagnosis masuk sepsis yang terbanyak yaitu 29 orang $(82,8 \%)$ dibandingkan dengan diagnosis lain yaitu severe sepsis sebanyak 4 orang $(11,4 \%)$ dan syok sepsis sebanyak 2 orang $(5,7 \%)$.

Tabel 1. Diagnosis masuk

\begin{tabular}{ccc}
\hline $\begin{array}{c}\text { Sepsis } \\
\text { (orang) } / \%\end{array}$ & $\begin{array}{c}\text { Severe sepsis } \\
\text { (orang) } / \%\end{array}$ & $\begin{array}{c}\text { Syok sepsis } \\
\text { (orang) } / \%\end{array}$ \\
\hline $29(82,8 \%)$ & $4(11,4 \%)$ & $2(5,7 \%)$ \\
\hline
\end{tabular}

Tabel 2. Diagnosis keluar

\begin{tabular}{ccc}
\hline $\begin{array}{c}\text { Sepsis } \\
\text { (orang) } / \%\end{array}$ & $\begin{array}{c}\text { Severe sepsis } \\
\text { (orang) } / \%\end{array}$ & $\begin{array}{c}\text { Syok sepsis } \\
\text { (orang) } / \%\end{array}$ \\
\hline $23(66 \%)$ & $2(6 \%)$ & $10(28 \%)$ \\
\hline
\end{tabular}

Tabel 3. Usia

\begin{tabular}{ccc}
\hline $\begin{array}{c}\text { Usia } \\
\text { (tahun) }\end{array}$ & $\begin{array}{c}\text { Jumlah } \\
\text { (orang) }\end{array}$ & $\%$ \\
\hline$\leq 14$ & 1 & 3 \\
$15-29$ & 3 & 9 \\
$30-44$ & 4 & 11 \\
$45-59$ & 12 & 34 \\
$60-74$ & 8 & 23 \\
$75-90$ & 7 & 20 \\
Total & 35 & 100 \\
\hline
\end{tabular}


Tabel 4. Penyakit dasar

\begin{tabular}{ccc}
\hline Penyakit dasar & $\begin{array}{c}\text { Jumlah } \\
\text { (Kasus) }\end{array}$ & $\%$ \\
\hline Pneumonia & 25 & 71,4 \\
Kolangitis & 1 & 2,8 \\
Urosepsis & 3 & 8,5 \\
ARDS & 1 & 2,8 \\
Ulkus dekubitus & 1 & 2,8 \\
Laparatomi & 3 & 8,5 \\
Ensefalopati & & \\
Tifoid & 1 & 2,8 \\
Total & 35 & 100 \\
\hline
\end{tabular}

Tabel 5. Perbandingan survival rate dan mortality rate

\begin{tabular}{cccc}
\hline $\begin{array}{c}\text { Lama } \\
\text { rawat } \\
\text { (hari) }\end{array}$ & $\begin{array}{c}\text { Jumlah } \\
\text { kasus (\%) }\end{array}$ & $\begin{array}{c}\text { Survival } \\
\text { rate } \\
\text { kasus (\%) }\end{array}$ & $\begin{array}{c}\text { Mortality } \\
\text { rate } \\
\text { kasus (\%) }\end{array}$ \\
\hline$<1$ & $11(31,4 \%)$ & $1(2,9 \%)$ & $10(28,6 \%)$ \\
$1-5$ & $17(48,6 \%)$ & $5(14,3 \%)$ & $12(34,3 \%)$ \\
$6-10$ & $2(5,7 \%)$ & $1(2,9 \%)$ & $1(2,9 \%)$ \\
$11-15$ & $1(2,9 \%)$ & $1(2,9 \%)$ & $0(0 \%)$ \\
$16-20$ & $2(5,7 \%)$ & $2(5,7 \%)$ & $0(0 \%)$ \\
$>20$ & $2(5,7 \%)$ & $2(5,7 \%)$ & $0(0 \%)$ \\
Total & $35(100 \%)$ & $12(34,3 \%)$ & $23(65,7 \%)$ \\
\hline
\end{tabular}

Tabel 6. Klasifikasi sepsis dan angka mortalitas

\begin{tabular}{cccc}
\hline $\begin{array}{c}\text { Mortalitas } \\
\text { (jam) }\end{array}$ & $\begin{array}{c}\text { Sepsis } \\
\text { kasus (\%) }\end{array}$ & $\begin{array}{c}\text { Severe } \\
\text { sepsis } \\
\text { kasus (\%) }\end{array}$ & $\begin{array}{c}\text { Syok } \\
\text { sepsis } \\
\text { kasus (\%) }\end{array}$ \\
\hline$\leq 12-23$ & $7(20 \%)$ & $1(2,9 \%)$ & $2(5,7 \%)$ \\
$24-48$ & $4(11,4 \%)$ & $1(2,9 \%)$ & $0(0 \%)$ \\
$>48$ & $7(20 \%)$ & $1(2,9 \%)$ & $0(0 \%)$ \\
Total & $18(78,2 \%)$ & $3(8,5 \%)$ & $2(5,7 \%)$ \\
\hline
\end{tabular}

\section{BAHASAN}

\section{Distribusi sepsis dan klasifikasinya berdasarkan jenis kelamin}

Angka kejadian sepsis tidak dipengaruhi jenis kelamin tetapi dipengaruhi usia dan jenis penyakit yang mendasarinya. ${ }^{1}$ Beberapa penelitian dilakukan terkait hubungan jenis kelamin dengan sepsis mendapatkan bahwa laki-laki lebih rentan terkena sepsis. Laki-laki cenderung mengalami infeksi di paru, sedangkan perempuan cenderung mengalami infeksi saluran kencing. Penyebab tersering untuk sepsis ialah infeksi paru. ${ }^{1}$ Penelitian lain mendapatkan hasil yang beragam yaitu perempuan memiliki $10 \%$ kemungkinan terkena sepsis dan meninggal dunia. Juga terdapat penelitian yang melaporkan bahwa jenis kelamin tidak berpengaruh bermakna terhadap sepsis. ${ }^{1}$

Penelitian di Amerika Serikat pada tahun 1979-2000 mengenai epidemiologi sepsis mendapatkan bahwa rata-rata usia untuk pasien sepsis jenis kelamin perempuan 62,1 tahun dan untuk laki-laki 56,9 tahun dengan jumlah penderita lakilaki yang lebih banyak. Menurut penelitian pada tahun 2008 tidak terdapat perbedaan atau hanya sedikit bperbedaan antara kedua jenis kelamin. $^{2}$

Data rekam medik pada penelitian ini memeperlihatkan bahwa jumlah pasien sepsis di ICU ialah 19 berjenis kelamin perempuan dan 16 berjenis kelamin lakilaki. Berdasarkan data penelitian ini terlihat bahwa jumlah pasien laki-laki dan perempuan cukup jauh berbeda dalam persentase namun tidak dapat disimpulkan mengenai kemaknaannya karena tidak dilakukan perhitungan statistik.

\section{Distribusi sepsis dan klasifikasinya berdasarkan usia}

Sepsis memang sudah menjadi masalah yang serius pada pasien dengan usia tua atau geriatri dan angka mortalitas meningkat sangat tajam seiring dengan bertambahnya usia. ${ }^{3}$ Berdasarkan data yang didapatkan di Amerika Serikat, lebih dari setengah pasien di ICU ialah pasien berusia 65 tahun ke atas dengan diagnosis penyakit kritis seperti sepsis.

Sepsis terbukti menjadi ancaman bagi pasien geriatri. Berdasarkan penelitian terdahulu pasien berusia $\geq 65$ tahun memiliki angka mortalitas sepsis yang tinggi dibandingkan dengan pasien yang lebih muda. ${ }^{3}$ Insiden sepsis meningkat tajam di usia dewasa-tua yaitu usia $<65$ tahun dengan $17,7 \%$ dan usia $>65$ tahun dengan $27,7 \%$. Pasien sepsis dengan usia geriatri juga meninggal lebih awal pada saat rawat inap; sekitar $26 \%$ meninggal dunia pada minggu pertama pada masa perawatan di rumah sakit. ${ }^{3}$ Seiring dengan bertambahnya usia maka sistem imun juga semakin menurun sehingga infeksi atau 
keadaan sepsis dapat lebih mudah terjadi.,

Pada penelitian ini didapatkan bahwa terdapat 13 pasien sepsis dengan kelompok usia 60-90 tahun, dan terdapat 1 pasien dengan severe sepsis dan 1 pasien dengan syok sepsis pada kelompok usia 65-74 tahun (Tabel 3). Hasil penelitian ini sejalan dengan hasil penelitian sebelumnya serta teori pendukung.

\section{Distribusi sepsis dan klasifikasinya berdasarkan diagnosis masuk dan diagnosis keluar}

Pada penelitian ini jumlah pasien dengan diagnosis masuk sepsis ialah 29 orang; severe sepsis 4 orang; dan syok sepsis 2 orang (Tabel 1). Hasil penelitian ini sejalan dengan penelitian sebelumnya di RS Dr. Sutomo yang mendapatkan pasien yang jatuh dalam keadaan sepsis berat sebesar 27,08\%, syok sepsis sebesar $14,58 \%$, sedangkan $58,33 \%$ sisanya hanya jatuh dalam keadaan sepsis. ${ }^{2}$ Hasil yang didapatkan penulis ialah $6 \%$ pasien dalam keadaan syok sepsis, $11 \%$ severe sepsis dan 83\% diantaranya ialah dalam keadaan sepsis. Dengan demikian yang paling banyak dirawat di ICU ialah sepsis kemudian severe sepsis dan yang terakhir ialah syok sepsis.

Dari diagnosis awal waktu masuk ICU hanya terdeteksi sebanyak 2 pasien syok sepsis, sedangkan dari diagnosis keluar terdeteksi 10 kasus dengan diagnosis syok sepsis (Tabel 2). Sepsis adalah keadaan SIRS dengan bukti infeksi sedangkan sepsis dengan kegagalan fungsi organ disebut severe sepsis dan severe sepsis dengan adanya keadaan hipotensi adalah syok sepsis. $^{5}$

Dari data yang didapatkan, 6 pasien sepsis dan 2 pasien severe sepsis terdiagnosis lanjut menjadi syok sepsis. Peningkatan jumlah kasus syok sepsis sebagai diagnosis akhir bisa disebabkan oleh karena terjadi komplikasi dalam perjalanan penyakit pasien yang sementara dirawat di ICU; bisa juga oleh karena tidak terdeteksi sejak awal yang menyebabkan angka kematian yang tinggi.

\section{Distribusi sepsis dan klasifikasinya berdasarkan penyakit dasar}

Mendiagnosis pasien dengan sepsis harus mempertimbangkan kemungkinan lokasi infeksi. Terdapat tiga lokasi infeksi yang sering pada sepsis, yaitu; paru, saluran kencing, dan luka bekas operasi. ${ }^{18}$ Penyakit dasar penyebab sepsis di ICU RSUP Prof. Dr. R. D. Kandou Manado yang paling banyak ialah pneumonia.

Data yang ditemukan dari catatan rekam medik ICU tidak mencantumkan hasil kultur terutama jenis kuman penyebab dan sensitivity test terhadap antibiotik sesuai kuman. Data juga tidak secara lengkap mencantumkan kategori sepsis, apakah pasien tersebut sepsis, severe sepsis atau syok sepsis.

Pasien di ICU memiliki resiko meninggal bukan hanya dari penyakit kritis yang diderita tetapi juga oleh penyakit nosokomial seperti infeksi. ${ }^{6}$ Pneumonia merupakan infeksi nosokomial paling umum kedua di ICU, menyerang kira-kira $27 \%$ dari pasien. Sekitar $86 \%$ dari penyakit nosokomial pneumonia terinfeksi dari penggunaan ventilasi mekanik yaitu Ventilator-Associated Pneumonia (VAP). ${ }^{6}$ Menurut penelitian sebelumnya di Amerika Serikat, angka mortalitas dari VAP sekitar 0-50\%. Hasil penelitian dapat menjadi beragam pada populasi yang berbeda.

Organisme penyebab VAP yang memiliki angka mortalitas paling tinggi ialah bakteri Gram negatif seperti Streptoccocus pneumonia, Klebsiella pneumonia, Pseudomonas aeruginosa, Acinetobacter dan Stenotrophomonas maltophilia. ${ }^{6}$ Berdasarkan data dan acuan pustaka, sepsis dengan penyakit dasarnya pneumonia paling banyak disebabkan karena penggunaan ventilasi mekanik sehingga terjadi VAP yang mendasari diagnosis sepsis pneumonia. ${ }^{6}$

Selain pneumonia, penyebab tersering sepsis selanjutnya ialah urosepsis dan laparotomi. Urosepsis rentan terjadi pada perempuan dan merupakan penyebab awal terjadinya sepsis. ${ }^{1,7}$ Sepsis yang terjadi berkaitan dengan infeksi pada bekas luka dapat terlihat dalam waktu 3 sampai 7 hari 
setelah operasi, tergantung kuman penyebabnya. Risiko terjadi infeksi pada bekas luka cukup tinggi sehingga angka kejadian sepsis yang disebabkan oleh infeksi pada bekas luka operasi (laparotomi) dilaporkan cukup tinggi (Tabel 4). ${ }^{7}$

\section{Perbandingan survival rate dan mortality rate pada sepsis dan klasifikasinya}

Angka mortalitas sepsis sangat tinggi, didukung oleh berbagai macam penelitian yang mendapatkan hasil serupa. ${ }^{8}$ Peneliti juga mendapatkan hasil yang serupa dimana angka mortalitas sepsis jauh lebih tinggi dari angka keselamatan pasien sepsis di ICU. Hal ini mungkin disebabkan karena pasien yang menjadi sampel penelitian sebagian besar ialah pasien berusia tua yang sangat rentan dengan sepsis. Dari 35 pasien, 23 orang $(65,7 \%)$ meninggal dunia sedangkan 12 orang $(34,3 \%)$ berhasil keluar dari ruang perawatan ICU dengan kondisi yang semakin membaik (Tabel 5). Pasien dengan diagnosis sepsis (dalam hal ini pasien yang mendapatkan perawatan dan kondisinya semakin membaik) rata-rata mendapatkan perawatan di ICU di bawah 7-14 hari. ${ }^{8}$

Terdapatnya angka mortalitas yang jauh lebih tinggi dibandingkan dengan angka lama rawat inap pasien terdiagnosis sepsis dan klasifikasinya bukan menjadi sesuatu yang mengejutkan lagi karena sudah banyak sekali hasil penelitian dan teori yang mendukung. ${ }^{8}$ Sepsis juga tergantung pada usia dan lokasi infeksi atau penyakit dasar. ${ }^{1}$

Saat sepsis berkembang menjadi severe sepsis dan syok sepsis, angka mortalitas juga akan meningkat. Didapatkan persentase angka mortalitas sebagai berikut: sepsis $20 \%$; severe sepsis $30-50 \%$; dan syok sepsis $50-80 \% .^{8}$ Penelitian sebelumnya menyebutkan bahwa biaya perawatan ICU untuk pasien dengan sepsis pada tahun 2009 di Amerika Serikat sebesar \$22.000 per pasien dan $\$ 17.000 .000 .000$ untuk satu negara. Biaya ini sama dengan biaya perawatan dari penyakit jantung iskemik (aterosklerosis). ${ }^{8}$
Pasien sepsis dengan usia tua sering meninggal lebih awal pada saat masa perawatan pasien di rumah sakit. ${ }^{8}$ Respon imun bawaan dan respon imun adaptif menurun oleh penuaan yang sebagian besar memberi kontribusi terhadap peningkatan kejadian infeksi pada orang tua. Respon imun adaptif yang rendah dikaitkan sebagai penyebab untuk fungsi kekebalan tubuh yang menurun di usia tua. Penelitian dalam dekade terakhir menunjukkan beberapa perubahan yang berkaitan dengan usia selsel dari sistem kekebalan tubuh bawaan yang juga merupakan faktor penyebab sistem imun menurun. Dalam sistem imun adaptif, jumlah sel $\mathrm{B}$ dan generasi sel $\mathrm{T}$ menurun oleh penuaan, yang menyebabkan berkurangnya sistem tanggapan terhadap patogen baru, namun kemampuan untuk melakukan respon yang efisien untuk patogen tetap utuh. ${ }^{3}$

Acuan pustaka menyebutkan bahwa pasien sepsis dengan usia tua cenderung meninggal lebih awal. ${ }^{1}$ Pada penelitian ini didapatkan pasien derajat sepsis terbanyak berusia 60-74 dan 75-90 tahun yang dikategorikan sebagai usia tua atau geriatri (Tabel 6). Mengingat data yang tidak lengkap mengenai etiologi kuman penyebab dan penanganan atau tindakan serta obat yang diberikan maka penulis berasumsi bahwa antibiotik yang diberikan kepada pasien yang merupakan pertahanan pertama terhadap infeksi tidak bekerja dengan baik atau tidak sesuai karena etiologi kuman penyebab tidak diketahui. Kemungkinan lain oleh karena angka resistensi yang cukup tinggi terhadap antibiotik. Hal ini juga mungkin terjadi oleh karena penggunaan atau konsumsi antibiotik yang tidak terkontrol, sehingga angka mortalitas lebih tinggi dibandingkan dengan angka morbiditas ataupun angka keberhasilan (angka keselamatan).

Dari 2 pasien syok sepsis yang terdiagnosis, kedua-duanya meninggal dan dari 4 pasien dengan severe sepsis, 3 orang meninggal dan hanya 1 yang selamat. Hal ini menunjukkan bahwa angka kematian syok sepsis tertinggi diantara klasifikasi sepsis lainnya, diikuti severe sepsis. 


\section{SIMPULAN}

Dari hasil penelitian di ICU RSUP Prof. Dr. R. D. Kandou dapat disimpulkan bahwa penderita sepsis didominasi oleh usia tua dengan angka kematian sepsis yang sangat tinggi $(65,7 \%)$.

\section{SARAN}

Dapat dilakukan penelitian yang lebih lengkap dan berkualitas mengenai pasien sepsis yang dirawat di ICU dengan memperhatikan parameter-parameter antara lain AGD, GCS, X-photo Thorax, ECG, dan yang terpenting ialah pemeriksaan kuman sehingga dapat diketahui etiologi kuman penyebab.

Kelengkapan pengisian status pasien sangat diperlukan guna menunjang pendekatan yang lengkap, akurat dan informatif sehingga dapat meningkatkan lagi penanganan dan dapat menjadi acuan penelitian lanjut.

\section{DAFTAR PUSTAKA}

1. Madsen T. Sex differences in sepsis. 2013 Aug 27. Available from: http://sgwhc.org/ resources/professionaleducation/case-studies/sex-differencessepsis/
2. Irawan D, Hamidah, Purwati, Triyono, Bramanto, Afianto $\mathrm{V}$, et al. Profil penderita sepsis akibat bakteri penghasil ESBL. J Peny Dalam. 2012; 13(1):63-8.

3. Starr M, Saiyo H. Sepsis in old ages: Review of human and animal studies. 2014. Available from: www.ncbi.nlm. nih.gov/pmc/articles/PMC3966671/?repo $\mathrm{rt}=$ classic

4. Martin LJ. Aging changes in immunity. 2014 Oct 10. Available from: https://www. nlm.nih.gov/medlineplus/ency/article/00 4008.htm

5. Barsten A, Soni N. Oh's Intensive Care Manual (6th ed). China: Butterworth Heinemann Elsevier, 2009.

6. Koenig SM, Truwit JD. Ventilator associated pneumonia: Diagnosis, treatment and prevention. Available from: www.ncbi.nlm.nih.gov/pmc/ articles/PMC1592694/

7. Jackson A, Connor M, Dreyer JS. Critical care and trauma part 8: Surgical sepsis. 2012. Available from: https://ptolemy. library.utoronto.ca/content/critical-careand-trauma-part-8-surgical-sepsis

8. O'Toole J, Katz MJ. Sepsis: Immune system melt down. 2014. Available from: https: //www.atrainceu.com/course/sepsisimmune-system-meltdown-107 